IZA DP No. 7962

Performance Effects of Appointing Other Firms' Executive Directors to Corporate Boards:

An Analysis of UK Firms

Alexander Muravyev

Oleksandr Talavera

Charlie Weir

February 2014

Forschungsinstitut zur Zukunft der Arbeit Institute for the Study of Labor 


\title{
Performance Effects of Appointing Other Firms' Executive Directors to Corporate Boards: An Analysis of UK Firms
}

\author{
Alexander Muravyev \\ St. Petersburg University GSOM and IZA \\ Oleksandr Talavera \\ University of Sheffield Management School \\ Charlie Weir \\ ABS, Robert Gordon University
}

Discussion Paper No. 7962

February 2014

\author{
IZA \\ P.O. Box 7240 \\ 53072 Bonn \\ Germany \\ Phone: +49-228-3894-0 \\ Fax: +49-228-3894-180 \\ E-mail: iza@iza.org
}

\begin{abstract}
Any opinions expressed here are those of the author(s) and not those of IZA. Research published in this series may include views on policy, but the institute itself takes no institutional policy positions. The IZA research network is committed to the IZA Guiding Principles of Research Integrity.

The Institute for the Study of Labor (IZA) in Bonn is a local and virtual international research center and a place of communication between science, politics and business. IZA is an independent nonprofit organization supported by Deutsche Post Foundation. The center is associated with the University of Bonn and offers a stimulating research environment through its international network, workshops and conferences, data service, project support, research visits and doctoral program. IZA engages in (i) original and internationally competitive research in all fields of labor economics, (ii) development of policy concepts, and (iii) dissemination of research results and concepts to the interested public.
\end{abstract}

IZA Discussion Papers often represent preliminary work and are circulated to encourage discussion. Citation of such a paper should account for its provisional character. A revised version may be available directly from the author. 


\section{ABSTRACT}

\section{Performance Effects of Appointing Other Firms' Executive Directors to Corporate Boards: An Analysis of UK Firms}

This paper studies the effect on company performance of appointing non-executive directors that are also executive directors in other firms. The analysis is based on a new panel dataset of UK companies over 2002-2008. Our findings suggest a positive relationship between the presence of these non-executive directors and the accounting performance of the appointing companies. The effect is stronger if these directors are executive directors in firms that are performing well. We also find a positive effect when these non-executive directors are members of the audit committee. Overall, our results are broadly consistent with the view that non-executive directors that are executives in other firms contribute to both the monitoring and advisory functions of corporate boards.

JEL Classification: $\quad$ G34, G39

Keywords: executive directors, non-executive directors, company performance

Corresponding author:

Charlie Weir

Aberdeen Business School

Robert Gordon University

Garthdee Road

Aberdeen

AB10 7QE

United Kingdom

E-mail: c.weir@rgu.ac.uk 


\section{INTRODUCTION}

The conflict of interest between managers on the one hand and providers of finance, most notably shareholders, on the other, is a key feature of the public corporation (Shleifer and Vishny 1997). Among various corporate governance mechanisms, which aim to realign these interests, a prominent role is assigned to corporate boards (Nordberg 2011). The issues of board structure and processes, defined in terms of board size, the establishment of various committees, the separation of the posts of the chairman of the board and the CEO, and nonexecutive director independence and representation have been central to recent corporate governance debates and reforms throughout the globe. The UK is no exception in this respect. Since the Cadbury Report (1992) there have been significant changes to board structures in that country. For example, McKnight and Weir (2009) show that duality, combining the posts of the chairman and the CEO, is now rare in UK quoted companies and Gregory-Smith (2012) reports a continuous increase in the percentage of non-executive directors classified as independent. In addition, the new UK Corporate Governance Code (2010) explicitly states that at least half of board should comprise non-executive directors.

The importance afforded non-executive directors in various codes of corporate governance as well as in a number of stock exchange regulations is based on the assumption that these directors exert a positive influence on company performance. This relationship has received considerable attention in empirical studies but the results are mixed at best. As noted by Goergen (2012, p.282), “The existing empirical literature provides little support for the effectiveness of independent, non-executive directors”. One reason for this may be the lack of attention given to the intrinsic heterogeneity of independent directors, defined along various dimensions, including professional experience and connections. 
One important dimension is that some non-executive directors may also be executive directors in other companies (hereafter we refer to these directors as NXXDs, Non-eXecutive eXecutive Directors). Many publicly quoted companies have boards that include nonexecutive directors that are simultaneously serving as executive directors on other boards. According to Spencer Stuart (2012 a), among 500 largest US companies from S\&P list, at least $25 \%$ of newly appointed directors are active CEOs. In the UK, among the largest 150 companies in the FTSE rankings, $40 \%$ of CEOs also serve on the boards of quoted company boards (Spencer Stuart 2012 b).

Theoretically, the appointment of NXXDs may have several implications for the performance of appointing firms. On the one hand, a company appointing NXXDs may benefit from their knowledge and experience, that is, their human capital as broadly defined. Such capital can enhance both the monitoring and advisory functions of the appointing firm's corporate board, the two key board functions identified in the corporate governance literature (Adams et al. 2010). The positive effect may be particularly pronounced when the NXXD already works in the same or similar industry and thus can bring industry-specific human capital to the appointing firm.

On the other hand, agency theory suggests a potential conflict of objectives when the same person acts as an executive director for one company but as a non-executive director for another. It is far from obvious that a CEO who is herself subject to monitoring and control by a board can be an effective monitor of another firm's CEO. As noted by Li and Qian (2011), NXXDs may sympathize with the executives they are supposed to control because of the similariy of their positions and may therefore make decisions that are detrimental to the company but which favor the appointing company's executives. 
Another potential problem with NXXDs is that they may be overcommitted or "too busy" to fulfil the advisory and monitoring functions in the appointing firm (Ferris et al. 2003; Fich and Shivdasani 2006). For example, the National Association of Corporate Directors in the US highlights substantial and increasing time commitments for board members, with one directorship requiring on average 228 hours or about 30 days of full-time work in 2011 (see Lublin 2012).

Finally, Fahlenbrach et al. (2010) suggest that appointing NXXDs may simply provide a certification benefit for the appointing firm without any effect on its decision-making and performance. In their words, “... if a firm succeeds in recruiting a CEO to its board, it shows to the outside world that a business leader whose human capital is especially reputationsensitive thinks highly enough of the firm to join its board” (p. 13).

The issues raised above suggest that the impact of NXXDs on the performance of the appointing companies is a non-trivial question which is important from both research and policy perspectives. However, despite the recent growth of interest in the topic, the empirical evidence on the role of NXXDs in corporate governance remains inconclusive and even contradictory (Fahlenbrach et al. 2010; Li and Qian 2011; Faleye 2011). This paper adds to the literature that deals with the performance effects of appointing other firms' executive directors to corporate boards. Consistent with the explicit advantages associated with nonexecutive directors, as set out in various codes of corporate governance and stock exchange regulations, our basic hypothesis maintains that the appointment of an executive director as non-executive director will have a positive impact on the appointing company's performance. Our empirical analysis is based on a new rich panel dataset of UK companies that is obtained by merging financial data from the Extel Financial database and director information from the Corporate Register over the period 2002 to 2008. 
We believe this paper makes several contributions to the corporate governance literature on the role of NXXDs. First, using a new and rich panel data from the UK and a number of model specifications, we provide new evidence on the effect on performance of appointing NXXDs to corporate boards. Second, we attempt to disentangle different channels through which NXXDs can influence, either positively or negatively, the performance of the appointing firms. Specifically, we evaluate whether the effect of appointing such directors depends on their human capital in general or their industry-specific human capital in particular. These factors are proxied by the performance of the firms where the NXXD serves as an executive director as well as by the degree of industry similarity between the firm that appoints the NXXD and the firm where she has an executive role. We also attempt to distinguish between the two key roles of non-executives: providing advice to the executive directors and monitoring their performance. In particular, we shed light on the capacity of NXXDs to monitor executives. To this end we exploit information on the participation of NXXDs in the audit committee of the appointing firm. Finally, to the best of our knowledge, ours is the first study of the effects of NXXDs on the performance of appointing firms in the UK.

Our results can be summarized as follows. First, we find support for the hypothesis that appointing a non-executive director who is already an executive director in another quoted company will have a significant and positive impact on the accounting performance of the appointing firm. Second, the positive impact on the performance of the non-executive director's firm is stronger the better the performance of the firm where the person is also an executive director. We interpret these results as evidence that the director's human capital creates positive outcomes for the appointing firm. Third, we find a positive relationship between the performance of the company measured by Tobin's Q and the NXXDs' membership of its audit committee. This suggests that NXXDs contribute to the monitoring 
function of corporate boards or, at least, that they do not impede such monitoring. Finally, we do not find strong evidence that the performance effects of NXXDs depend on the degree of industry similarity between the firms where these directors hold their posts. Industry similarity seems to matter only when NXXDs are members of the audit committee. Overall, this finding casts doubt on the idea that general managerial skills of NXXDs are of less importance as compared to their industry-specific human capital.

The paper is organized as follows. The next section discusses the relevant literature and outlines the specific hypotheses to be tested. Section 3 sets out the econometric modeling strategy. Section 4 presents the data. The results are discussed in Section 5. Finally, Section 6 draws some conclusions.

\section{LITERATURE REVIEW AND HYPOTHESIS DEVELOPMENT}

\subsection{Literature review}

The relationship between non-executive director representation and firm performance is subject to controversy and debate (Goergen 2012). A number of studies have found a positive relationship between the percentage of non-executive and/or independent directors and company performance, for example, Weir at al. (2002), Mura (2007) and Knyazeva et al. (2013). In contrast, others have reported a negative relationship, for example Agrawal and Knoeber (1996), Bhagat and Black (2002), Adams and Ferreira (2009) and Carter et al. (2010). Most commonly, an insignificant relationship is found, for example, Mehran (1995), Faccio and Lasfer (2000) and Wintoki et al. (2012). The main cross-country study to date, Dahya et al. (2008) reports a positive effect of board independence on corporate value. However, Black et al. (2012) cast doubt on the robustness of this result by noting that "board independence predicts higher market value in Korea, lower market value in Brazil and is insignificant in India” (p. 937). 
In an attempt to explain these contradictory findings, many scholars have recently turned attention to the issue of director heterogeneity, including demographics, professional experience, and contacts (e.g., Anderson et al. 2011; Kang 2012). One key aspect in this emerging literature is multiple directorships, and in particular the case when non-executive directors also serve as executive directors in other firms, whom we call NXXDs.

In the literature, it is widely admitted that the appointing firm can benefit from NXXDs because they have accumulated significant human capital, including knowledge, experience, and authority. These factors are important for board effectiveness. A survey by Johnson et al. (2013), which distinguishes between several elements of directors' human capital, including industry experience, experience as a CEO, venture capital experience, and financial expertise, concludes that ...it is clear that human capital affects the board's activities since directors' experiences and proficiencies affect their cognitions and decisions” (p. 243).

Many empirical studies provide indirect evidence on the importance of human capital by showing the importance of managers' and directors' fixed effects in explaining corporate decisions and performance. For example, Bertrand and Schoar (2003) show that top manager fixed effects explain decisions in the areas of investment, finance and organizational practices. Richardson et al. (2003) also find evidence of director fixed effects in relation to governance, finance, disclosure and strategic policies. Fahlenbrach et al. (2010) and Chen (2008) report a link between the policies of directors who sit on different boards.

The importance of independent directorship experience for firm performance is highlighted in a recent paper by Kang (2012). The author finds that both board independence and the fraction of experienced independent directors, two measures of board quality, are positively associated with firm performance (albeit only for firms that face weak product market competition). The effect of board independence, however, disappears if both measures of 
board quality are used simultaneously in the regression analysis. Therefore, it appears that both independence and experience matter, not independence per se.

Several papers suggest the importance of distinguishing between general and industryspecific capital. For example, both Faleye (2011) and Fahlenbrach et al. (2010) cast doubt on the importance of general managerial skills (as measured by directors with CEO-level experience) for board effectiveness, as compared with industry-specific skills. Indeed, Custódio and Metzger (2013), who analyze the effect of CEO industry expertise in diversifying acquisitions, find significant positive abnormal returns when the acquirer's CEO had had top management experience in the target's industry. However, Aivazian et al. (2010), who investigate the relationship between CEO human capital and investment and financing decisions, report that when CEOs with more general skills are matched with firms requiring these generalised skills, shareholders benefit from higher profits. The empirical evidence is thus mixed.

Another strand of the literature attempts to disentangle the contribution of non-executive directors, including NXXDs, to monitoring and advising executive directors. Adams and Ferreira (2007) show that the effectiveness of non-executive directors in relation to monitoring and advising depends on the costs of gaining relevant information. There is also evidence to suggest the existence of a trade-off between the two roles. For example, Chen (2008) proposes that the cost of fulfilling the advisory function is a consequent reduction in monitoring effectiveness and higher agency costs. His model suggests that it is not optimal for the board to advise unless its ability to do so is high enough to overcome these costs. In the empirical test carried out in the paper, independent directors' propensity to advise is proxied by their affiliation with other companies in the capacity of executive directors. Chen finds that firms with these directors are likely to outperform their counterparts that do not 
have these affiliations. Thus, for boards with NXXDs, any potential reduction in monitoring effectiveness is more than compensated by better advice.

In general, monitoring by NXXDs is an issue because of a potential conflict of attitudes and perspectives when the same person acts as an executive director for one company and as a non-executive director for another. As noted by Li and Qian (2011) “...social psychological theory suggests that these directors, due to their similar positions and experiences with the company CEO, are likely to be sympathetic with, and lenient on, the company CEO, hence not performing their fiduciary duty effectively” (p. 130). Their empirical evidence, based on US data, is consistent with the sympathy hypothesis that outside CEO directors are inclined to make decisions in favor of the company CEO.

In a similar vein, Faleye (2011) finds that, in the presence of CEO directors, executives are paid more and their compensation is less sensitive to firm performance. This excess pay cannot be explained by economic factors associated with the riskiness of the job. Overall, the results suggest that potential advisory benefits of CEO directors must be balanced against simultaneous distortions in executive incentives in the appointing firm.

On the other hand, Fahlenbrach et al. (2010) do not find any evidence that directors' incentives are distorted by having CEOs on the board. In fact, their results suggest that CEO directors do not affect the appointing firm's operating performance, decision-making, and CEO compensation. For the appointing firm's executives, a CEO director simply brings a certification benefit that the firm is on the right path.

A separate strand of literature focuses on busy directors. The key question is whether directors who serve on several boards are over-committed and therefore unable to fulfil the role of effective monitors. The empirical evidence regarding the effect of "busy" directors is mixed. Most empirical studies, including Core et al. (1999), Fich and Shivdasani (2006) and 
Cashman et al. (2012) report some support for the busyness hypothesis. For example, Core et al. (1999) conclude that busy outside directors on the board are associated with greater CEO compensation, suggesting weak corporate governance. Fich and Shivdasani (2006) show that firms with busy boards, that is, those with a majority of their outside directors having three or more additional board seats, are associated with weaker corporate performance. However, Ferris et al. (2003), who investigate the frequency of subsequent securities fraud lawsuits and firm performance, find no evidence of busy directors shirking their responsibilities.

Finally, Field et al. (2013) report a positive association between busy directors and the performance of IPO firms. These firms seem to benefit from the experience and contacts of busy directors. In contrast, benefits of appointing busy directors do not extend to most established firms which require more monitoring than advising.

The above literature review highlights considerable controversy regarding both the overall effect of NXXDs on corporate performance and potential channels of such influence. This paper, based on new rich data from the UK, addresses several of these highly debated issues, namely, the overall effect of NXXDs, importance of general versus industry-specific human capital, and contribution of NXXDs to the monitoring function of corporate boards. The exact formulation of the hypotheses tested in our study is provided in Section 2.2 below.

\subsection{Hypothesis development}

Based on the discussion above, our basic proposition is that firm performance is positively related to the presence of NXXDs. Undertaking the role of an executive director, ceteris paribus, implies the accumulation of managerial knowledge and skills that are likely be useful to the firm where the person works as non-executive director. These human capital characteristics can enhance both the monitoring and advisory functions of a corporate board and thus contribute positively to company performance. Therefore our first hypothesis is: 
H1: The presence of NXXDs on the board has a positive relation with year-ahead firm performance.

Our second hypothesis takes account of the fact that the human capital of an independent executive can be proxied by the performance of the company where the non-executive director is employed as an executive director. One problem with relating director quality to firm performance is that the latter may be influenced by a variety of factors beyond managerial control, such as an overall economic downturn or industry shock. Firm performance is therefore a very noisy measure of director quality. This issue is addressed in the literature by using relative performance indicators which compare the performance of a company to the performance of firms in the same industry or market (e.g., Parrino 1997; DeFond and Park 1999; Muravyev 2003). This is also the approach adopted in our study. We measure human capital, that is, the quality of an outside director, by the relative performance of the firm in which she is an executive director. The second hypothesis therefore is:

H2: The positive relation between the presence of NXXDs on the board and year-ahead performance is more pronounced if the NXXD is from a firm with greater relative performance.

As suggested in the literature, it may be industry-specific human capital and not general managerial skills of NXXDs that help improve the performance of the appointing firms. In order to test this hypothesis, we distinguish between NXXDs who hold executive and nonexecutive positions in the same industry from those who are involved in firms from different industries. While the amount of general managerial skills of NXXDs may be the same in both cases, the amount of industry specific human capital is likely to be larger in the former case. We thus consider the following proposition: 
H3: The positive relation between the presence of NXXDs on the board and year-ahead firm performance is more pronounced if the director comes from a firm in the same industry.

We further advance the analysis of the relative importance of general versus industry-specific human capital by considering the interaction of industry similarity and the relative performance of a firm where the NXXD is an executive director. Our prior is that these factors reinforce each other, in particular, we hypothesise that:

H4: The positive relation between the presence of NXXDs on the board and year-ahead firm performance is more pronounced if the director comes from a firm with relative greater performance in the same industry.

The agency model emphasizes the monitoring role of non-executive directors. Chen (2008) argues that, by concentrating on the advisory role, monitoring will suffer and firms will incur agency costs. We test the monitoring role by means of membership of the audit committee. The responsibilities of the audit committee and its members have been set out in various UK reports, the latest being The UK Corporate Governance Code (2010). Audit committee members have a specific set of roles and responsibilities including monitoring the integrity of the company's financial statements, monitoring the effectiveness of the internal auditing systems, reviewing the company's internal financial controls and to ensure that possible financial problems are raised. These responsibilities should therefore result in better financial decision-making and better financial performance. This gives the following hypothesis:

H5: The presence of NXXDs on the audit committee is positively related to firm performance.

Finally, the reduction of agency problems may depend on the quality of the monitoring mechanism (e.g., the capacity of independent directors to process relevant information). We 
proxy the latter by the interaction of industry characteristics (NXXDs from a similar industry) and audit committee membership. Thus, we hypothesise:

H6: The positive relation between the presence of NXXDs on the audit committee and yearahead firm performance is more pronounced if the director comes from a firm in the same industry.

\section{RESEARCH DESIGN AND EMPIRICAL MODELS}

This basic hypothesis is set out in the first and simplest empirical model, in which we relate the performance of a company to the presence of NXXDs on its board. In particular, we consider the following specification:

$$
P E R F_{i t}=\beta N X X D_{i t-1}+X_{i t-1} \gamma+\delta_{t}+\xi_{i}+\varepsilon_{i t}
$$

where $i$ is the firm index, $t$ is the time index, $P E R F_{i t}$ stands for the performance of the receiving firm $i$, and variable $N X X D_{i t-1}$ indicates the presence of a non-executive director that is also an executive director. Vector $X_{i t-1}$ contains a set of control variables which are traditionally included in studies of firm performance, $\delta_{t}$ is a time specific effect, $\xi_{i}$ is a firm specific effect, which encompasses all unobserved time-invariant characteristics of the firm potentially affecting its performance, and $\varepsilon_{i t}$ is a random disturbance. Of primary interest to us is the coefficient $\beta$ on variable $N X X D_{i t}$. In accordance with our basic hypothesis, we expect $\beta$ to be positive.

The choice of methodology depends crucially on the nature of our data with respect to changes in NXXD directorships. For example, if the NXXD presence is time-invariant, the fixed effects estimator is not appropriate and regressions should be run by year or, alternatively, performance should be averaged across the years. If firms generally add 
NXXDs to the board over time, one might think about employing a difference-in-difference design. However, our data reveal that about 10 percent of firms have changes (both increases and decreases) in number of NXXDs each year. Importantly, this figure is consistent over the time span. Therefore, we believe that fixed effects estimator is appropriate in our case.

We employ three different measures of performance: return on equity (ROE) which is defined as profit after taxes divided by book value of shareholders' equity; return on sales (ROS), calculated as EBIT divided by total turnover; and Tobin's Q. ${ }^{1}$ The latter indicator is calculated as the ratio of the firm's market capitalization and book value of debt to the book value of total assets. ${ }^{2}$ We analyse the effect of NXXDs using two measures. First, we employ $N X X D_{i t-1}$, a dummy variable which takes the value of 1 if at least one non-executive director is also an executive director of another company and 0 otherwise. Second, Number of $N X X D_{i t-1}$ is defined as the number of non-executive directors on the board who are also executive directors in other companies.

The elements of vector $X_{i t-1}$ control for firm-specific characteristics that influence firm performance. The choice of our control variables is based on earlier studies of company performance in cross-sectional and panel data settings. To control for firm size, we include the natural $\log$ of the number of employees, $\log \left(\right.$ Labour $\left._{i t}\right)$ (Coles et al. 2008). The financial strength of a firm is measured by the variable Leverage $i$, calculated as ratio of long term debt over total assets (Weir et al. 2002). Our specifications with Tobin's Q as the dependent variable also include an accounting performance measure, ROE. In order to mitigate potential endogeneity problems, we lag all financial variables that appear on the right hand side of our regression models. Finally, to control for corporate governance characteristics we include in

\footnotetext{
${ }^{1}$ In addition to ROE and ROS, we have also experimented with return on assets (ROA) and return on capital employed (ROCE). The results are qualitatively similar.

${ }^{2}$ We have also reestimated our regressions with another measure of Tobin's Q, calculated as market capitalization divided by book value of the firm's assets. The estimation results are similar to those reported in the tables below.
} 
vector $X_{i t-1}$ the total number of executive and non-executive directors, Board Size ${ }_{i t-1}$ (Yermack 1996); the ratio of the number of non-executive directors to the total number of directors, Share $N E_{i t-1}$ (Mura 2007); variable New $N X_{i t-1}$, which is a dummy taking the value of 1 if a new outside director was appointed in a given year and 0 otherwise (Vafeas 2003); and $N X 3_{i t-}$ 1, the indicator for outside directors serving on three or more boards (Fich and Shivdasani 2006).

We then extend our analysis by taking into account independent executives' human capital. It is proxied by the relative performance of the firm in which these directors have executive positions:

$$
P E R F_{i t}=\beta N X X D_{i t-1}+\theta R E L_{-} P E R F_{i t}+X_{i t-1} \gamma+\delta_{t}+\xi_{i}+\varepsilon_{i t}
$$

We define the relative performance of a firm $\left(R E L \_P E R F_{i t}\right)$ where the NXXD is an executive director as the difference between its reported performance and the median performance of all sampled firms belonging to the same industry and observed in the same year.

We then investigate whether the effect of independent directors varies with the degree of industry similarity between the firms where these directors have their jobs. First, we consider the impact of appointing an independent executive director who is also an executive director in a firm that operates in the same industry where these industries are defined in the Extel database. We hypothesize that directors who work as executive directors in the same industry as that of the appointing firm will enhance the quality of advice offered to the appointing firm. This suggests that the human capital of these directors will be more beneficial than that of a director without such a detailed knowledge and understanding of the sector. However, the relationship may also be affected by competition considerations given that the two companies may be competitors. The model therefore takes the following form:

$$
P E R F_{i t}=\varphi_{1} S A M E \_I N D_{i t-1}+\varphi_{2} D I F F \_I N D_{i t-1}+\theta R E L \_P E R F_{i t}+X_{i t-1} \gamma+\delta_{t}+\xi_{i}+\varepsilon_{i t}
$$


where $S A M E \_I N D_{i t-1}$ is a dummy variable which takes the value of 1 if at least one of the non-executive directors of firm $i$ is an executive director of a company in the same industry and 0 otherwise. DIFF_IND $D_{i-1}$ is a dummy variable which takes the value of 1 if a firm has at least one NXXD, but she works in a different industry and 0 otherwise.

Next, we focus on the interaction between industry similarity and average relative performance. Industry similarity is measured based on the Extel database classifications. This gives us the following model:

$P E R F_{i t}=\varphi_{1} S A M E \_I N D_{i t-1}+\varphi_{2} D I F F_{-} I N D_{i t-1}+v_{1} R E L \_P E R F \times$ xAME_IND $D_{i t-1}+$

$v_{2} R E L \_P E R F \times$ DIFF_IND $D_{i t-1}+X_{i t-1} \gamma+\delta_{t}+\xi_{i}+\varepsilon_{i t}$

Next we analyse the monitoring implications of NXXDs by investigating the impact on performance of having independent executive directors as members of the audit committee of the firm. The audit committee can be regarded as a proxy for the monitoring function of independent directors because its main responsibilities include monitoring the quality of the financial statements published by the company, monitoring the effectiveness of the company's internal auditing function and reviewing the company's internal financial controls. Indeed, as noted by Stiles (2013), the role of board committees, including audit committee, in enhancing corporate governance and improving form performance "lies primarily in their potential for independent monitoring” (p.177).

The model therefore transforms into:

$P E R F_{i t}=\beta N X X D_{i t-1}+\theta R E L \_P E R F_{i t}+\psi A U D I T_{i t-1}+X_{i t-1} \gamma+\delta_{t}+\xi_{i}+\varepsilon_{i t}$,

where audit committee membership, $A U D I T_{i t-1}$ is defined as a dummy variable which takes the value of 1 if an NXXD sits in the audit committee and 0 otherwise. 
Finally, we consider the interaction of the audit committee membership dummy with the dummies for similar and different industries:

$$
\begin{aligned}
& P E R F_{i t}=\varphi_{1} S A M E \_I N D_{i t-1}+\varphi_{2} D I F F_{-} I N D_{i t-1}+\theta R E L \_P E R F_{i t}+\eta_{1} S A M E_{-} I N D_{i t-1} \times A U D I T_{i t-1}+ \\
& \eta_{2} D I F F_{-} I N D_{i t-1} \times A U D I T_{i t-1}+X_{i t-1} \gamma+\delta_{t}+\xi_{i}+\varepsilon_{i t},
\end{aligned}
$$

\section{DATA DESCRIPTION}

The data for this study have been collected from two sources. First, financial data are drawn from the Extel Financial database. The advantage of this database is its use of consistent financial report information across a large number of industries. Our initial sample contains about 5,000 UK listed companies observed between 2002 and 2008. Second, information about executive and non-executive directors has been hand collected from the Corporate Register. All performance data refer to the end of the financial year as reported in the companies’ financial statements in Extel, for example, 2008. The board structure data refer to the position at the end of the previous financial year as reported in the Corporate Register, for example, 2007. This identifies the board structures that are in place at the beginning of the relevant financial year and which were therefore responsible for determining company performance during that year. This feature of the data on board structure is reflected with subscripts t-1 in the regression models (1) to (6).

Overall, there are about 130,000 director-years during the seven years considered. The databases have been merged based on company name. While both database providers claim that they cover the population of listed companies, only about 50 percent of observations are present in both the firm-level and director-level datasets. Our initial sample links around 68,000 directors with financial information of companies. The sample was constructed in the following way. First, we dropped all company-years that do not report either executive or 
non-executive boards. Second, we removed all firms that report either negative equity or negative total assets. At this point the data consisted of about 57,000 director-company-year observations pertaining to 8,506 firm-years. Third, to address the issue of firms in severe financial distress, we have dropped companies that report ROE or ROS less than -1 . Fourth, to reduce the effect of outliers we winsorized 1\% observations from the left and right tails of the distribution of all financial variables. ${ }^{3}$ Finally, given that we intend to make use of some lagged values in our regression specification, we require at least two years' worth of data. The final estimation data set consists of 3,977 firm-years.

\section{INSERT TABLE1}

Table 1 presents an overview of the variables. Among the sampled firms, the average board has about 7.23 directors and the average share of non-executive directors is $52 \%$. This is similar to what was reported in previous studies, such as Weir and Laing (2003) and Guest (2008). Table 1 also shows that 20\% of the sampled firms have non-executive directors that are also executive directors in other firms. On average 6\% of non-executive directors are also executive directors in other companies, a finding consistent with Higgs (2003). This, and the other board structure statistics, suggests that there is no systematic selection bias in our sample.

Regarding the financial variables, the average (median) firm holds $21 \%$ (16\%) of their total assets as long term debt. As expected, all firms report positive average performance during the time period examined.

In relation to audit committees, we report that $10 \%$ of the firms have a non-executive director who is also an executive director as a member. Although not reported in the table, $2 \%$ of the firms have on their audit committees a non-executive director who is an executive director of

\footnotetext{
${ }^{3}$ We have also tried dropping financial variables as well as applying different cut-off points for outliers (2\% and $5 \%$ instead of $1 \%$ ). In all these cases the results are very similar to those reported below.
} 
a firm in the same industry. We also find that $4 \%$ of the sampled firms have someone on the audit committee who is an executive director in a similar industry.

Table 2 shows descriptive statistics for two subsamples: firms that have NXXDs and those that do not. We report significant differences between the characteristics of the two types of firms. For example, firms with non-executive directors that are also executive directors in other firms use, on average, significantly more debt than other firms (24\% relative to $20 \%$ ). In terms of employment, we find that firms with non-executive directors are significantly bigger. They have larger boards with, on average, 8.37 members as compared with 6.94 members in the other firms. They also have a significantly larger percentage of non-executive directors on the board, $57 \%$ as opposed to $51 \%$.

The performance measures show that companies with NXXDs have, on average, better performance that firms without NXXDs. This is consistent with Chen (2008). For example, companies with NXXDs have, on average, six percentage points superior performance in terms of ROE and three percentage point superiority in terms of ROS. Firms with NXXDs also have higher Tobin's Q ratios than firms without such directors. The last column of Table 2 reports the differences in medians and their statistical significance based on a nonparametric K-sample test.

\section{INSERT TABLE2}

\section{RESULTS}

\subsection{Main results}

The results in Table 3 show the impact of NXXDs on the appointing firm's performance, as measured by ROE, ROS, and Tobin's Q. Columns (1) - (3) show the results for the first NXXD measure, a dummy variable that takes the value of 1 if a firm has a non-executive director who is also an executive director and 0 otherwise. Columns (4) - (6) report the 
estimates when the NXXD variable measures the number of non-executive directors that are also executive directors. The results are obtained using the fixed effects estimator.

Both ROE and ROS models show a positive and significant relationship between firm performance and the presence of non-executive directors. For example, firms with NXXDs are likely to have 2.7 percentage points higher ROE compared to firms without NXXDs. We also find a positive and significant relationship between the number of NXXDs and accounting performance. However, the regressions with Tobin's Q reveal statistically insignificant effects. Importantly, the results for the two measures of NXXDs turn out to be very similar. In what follows we therefore primarily focus on the first measure, a dummy variable for the presence of at least one non-executive director who is also an executive director in another firm.

\section{INSERT TABLE3}

Table 4 develops the analysis by evaluating how the effect of NXXDs varies with relative performance and the degree of industry similarity between the firms in which NXXDs have jobs. Columns (1) - (3) contain regressions augmented with measures of the relative performance of the company where the non-executive director is an executive director. Each specification includes a relative performance measure which matches the dependent variable. For example, since ROE is the dependent variable in Column (1), the relative performance measure is also based on ROE. ${ }^{4}$

The association between the presence of NXXDs and the performance of the appointing firms remains similar to those reported above. We should note that the effect of NXXDs is now proxied by two variables, the NXXD dummy and a measure of relative performance of the "sending” firm. While the coefficients on the former lose statistical significance as compared

\footnotetext{
${ }^{4}$ If there is more than one NXXD then the relative performance measure is the average of the NXXDs relative performance in their firms.
} 
to the results in Table 3, there is a positive and significant relationship between the accounting performance of the appointing firm and the relative performance of the firm where the NXXD is an executive director. In terms of magnitude, a two standard deviations increase in the relative ROE of the company where director holds an executive position increases ROE of the appointing company by 0.023 . This is a substantial increase given that the average (median) ROE is 0.06 (0.09). We interpret this result as evidence that the appointing firm gains some of the director's human capital in the form of better quality advice. Thus the advantage of being responsible for effective strategies and policies as an executive director also produces benefits in the role of non-executive director. The result is in line with Chen (2008) who reports a positive relationship between a non-executive director's advisory function and firm performance. It is also consistent with the findings in Kaplan and Reishus (1990) and Fich (2005) suggesting that executives in companies that perform well are more likely to be appointed non-executive directors in other companies.

Columns (4) - (6) of Table 4 report the results for the specifications in which we distinguish between NXXDs working for the firms in the same industry and those working for the firms in different industries. According to these results, there is little evidence that the degree of industry similarity (which helps differentiate between general managerial skills and industryspecific capital of NXXDs) actually matters for the appointing firm performance. Only in the regression with Tobin's $\mathrm{Q}$ as the dependent variable we observe a sizeable difference in the coefficients. However, even in this case it remains statistically insignificant. These results suggest that the positive performance effects of NXXDs may stem not only from their industry-specific skills, but also from their general skills. Another explanation for the limited role of industry similarity may be related to potential competition between the "sending" and "receiving” firms. Indeed, executive directors that sit on the boards of competitors may be in a difficult position in relation to the advice they give. Therefore they have a potential conflict 
between their reputational interests and their concerns about offering a competitor some advantage.

Next we interact relative performance and industry similarity. REL_PERF $\mathrm{x}$ SAME_IND is the interaction of the industry adjusted profitability of the company where the NXXD is an executive director and dummy variable $S A M E \_I N D$ which has the value of 1 if the NXXD director comes from a similar industry and 0 otherwise. REL_PERF $\mathrm{x}$ DIFF_IND is the interaction of the industry adjusted profitability of the company where the NXXD is an executive director and dummy variable DIFF_IND which takes the value of 1 if the NXXD director comes from a different industry and 0 otherwise. The baseline category in this case is no NXXDs.

The estimates in columns (7) - (9) of Table 4 report no significant effect for relative performance when non-executive directors are appointed from a different industry. However, Column (8) shows a positive and statistically significant coefficient on the interaction of industry similarity and relative profitability measured by ROS. Thus, there is some (albeit weak) evidence that NXXDs contribute more to the appointing firm when they have executive positions in the same industry.

\section{INSERT TABLE 4}

We proceed with the analysis of the possible role of NXXDs in monitoring executive directors. For that purpose we introduce in the regressions variable AUDIT, a binary variable equal to one if an NXXD is in the audit committee.

Columns (1) - (3) of Table 5 report the results for audit committee membership. In particular, our estimates suggest that having NXXDs on the audit committee has no effect on accounting performance as measured by ROE or ROS. Column (3) shows that having NXXDs on the audit committee has a positive and statistically significant effect on market performance, 
measured by Tobin's Q. This is an important result because it shows that, within the UK context, NXXDs produce positive returns on both the advisory and monitoring functions. The result for monitoring is contrary to those reported in Li and Qian (2011) and Faleye (2011) but is largely consistent with Fahlenbrach et al. (2010). Further, it should be noted that NXXDs in our study are defined as any executive directors (and not just CEOs as in most other studies) who serve as non-executives in other firms. It may well be the case that the sympathy hypothesis advanced by Li and Qian (2011) does not apply to NXXDs who are executives, but not CEOs, in their primary firms.

We further develop the analysis by investigating whether the effectiveness of monitoring by NXXDs depends on the degree of industry similarity between the firms they are involved in. As in the case of relative performance above, we analyze the interactions of industry similarity and the audit committee membership of NXXDs. In particular, AUDIT $\mathrm{x}$ SAME_IND has the value of 1 if a company has an audit committee non-executive director who is also an executive director in the same industry and 0 otherwise. AUDIT x DIFF_IND has the value of 1 if there are audit committee non-executive directors who are executive directors in other companies, but none of them work in a company from the same industry and 0 otherwise.

Columns (4) - (6) of Table 5 report the results for the regressions with such interactions. In terms of audit committee membership impacts, Table 5 shows that having independent nonexecutive directors from the same industry on the audit committee raises Tobin's Q but does not affect either ROE or ROS. These results suggest that the market regards appointing a nonexecutive director who is an executive director in the same industry as positive but that the benefit is not reflected in better accounting performance.

INSERT TABLE 5 
Columns (4) - (5) also reveal positive effect of the relative performance on ROE and ROS. However, as column (6) shows, it does not affect Tobin's Q ratio. We find an insignificant result for the same industry measure for all three performance measures, which is consistent with the previously reported findings.

\subsection{Dynamic panel data robustness analysis}

Models (1) - (6) are estimated without controlling for profitability persistence which might be an important control variable (e.g. Goddard and Wilson, 1999; Crespo-Cuaresma and Gschwandtner. 2008). We address this by amending our baseline model (1) to include a lagged dependent variable which allows us to control for the potential impact of performance persistence. ${ }^{5}$ Our dynamic model takes the following form:

$$
P E R F_{i t}=\lambda P E R F_{i, t-1}+\beta N X X D_{i t-1}+X_{i t-1} \gamma+\delta_{t}+\xi_{i}+\varepsilon_{i t}
$$

where $P E R F_{i, t-1}$ is the performance of the appointing firm in period $\mathrm{t}-1$.To estimate equation (7) we have to take into account the potential endogeneity of financial performance and board appointment decisions. Furthermore, including the lagged dependent variable as an independent variable makes the fixed effects estimator not only biased, but also inconsistent. To address this issue, we make use of the dynamic panel data (DPD) estimator which employs a matrix of lagged endogenous variables as instruments timed from t-2 to t-6. All our models are estimated with the two-step GMM System variant of the (DPD) estimator, which combines equations in differences of the variables (instrumented by lagged levels) with equations in levels of the variables (instrumented by lagged differences). In addition, year dummy variables are included in the regressions as exogenous.

This approach also assists us in addressing issues of endogeneity in relation to board appointments and performance, Hermalin and Weisbach (2003) and Drakos and Bekiris

\footnotetext{
${ }^{5}$ We have also re-estimated our models (2) - (6) using Dynamic Panel Data approach and obtained qualitatively similar results. They are available upon request.
} 
(2010). For example, as specified, NXXDs positively affect the appointing firm's performance. However, it may be the case that high performing companies attract better NXXDs. Employing a DPD estimator is particularly beneficial when it is not easy to find an appropriate instrument for corporate governance variables.

The reliability of the DPD results depends crucially on the assumption that the instruments are valid. This can be checked by employing the Hansen test of overidentifying restrictions. A rejection of the null hypothesis that instruments are uncorrelated to errors would indicate inconsistent estimates. In addition, we also present test statistics for second-order serial correlation in the error process. In a dynamic panel data context, we expect first order serial correlation, but should not be able to detect second-order serial correlation if the instruments are orthogonal to the errors.

Table 6 reports GMM-SYS dynamic panel data results. The results are comparable to the fixed effects estimates reported in Table 3. Models (1) - (3) show that the presence of NXXDs has a positive effect on the appointing firm's performance with the respective regression coefficients being positive and significant for ROE and ROS, but not for Tobin's Q. We also find, in models (4) - (6), that the greater the number of NXXDs, the better the appointing firm's performance. Similar to models (1) - (3), the coefficient of interest is significant for accounting performance measures. Importantly, all model specifications pass the test for the second-order autocorrelation as well as the Hansen test of the validity of the instruments at the $5 \%$ significance level.

\section{INSERT TABLE 6}




\section{CONCLUSIONS}

This paper studies the impact of appointing executive directors as non-executive directors on the appointing firm's performance. Our results, based on a rich new dataset from the UK, suggest a positive link between the presence of an NXXD and the appointing firm's performance. Specifically, the analysis shows that the better the relative performance of the firm where the director is an executive, the better the appointing firm's performance. This indicates that directors' human capital matters, most likely, for the quality of advice offered by them.

We further find some evidence that membership in the audit committee has a positive effect on the appointing firm's performance. This result is consistent with a non-trivial contribution of NXXDs to the monitoring function of corporate boards. Overall, our results are consistent with the view that the appointing firm gains from both advice and monitoring by nonexecutive directors and suggest that having such directors as non-executives on the corporate board generates benefits for shareholders.

The analysis has identified a number of areas for further research. First, the lack of a strong relationship between the performance and appointment of NXXDs from the same industry may provide additional insights into the potential tension between advice and possible competition effects. Second, the distinction between types of non-executive directors, those already executive directors and those not, may provide a better understanding of the monitoring and advisory roles of corporate boards. Third, the impact of social capital and its interaction with human capital may offer additional insights into explaining firm performance. 


\section{Acknowledgements}

Financial support for the project from the British Academy is gratefully acknowledged. Grant NO R18271.

\section{References}

Adams R Hermalin B, Weisbach M. (2010) The role of boards of directors in Corp governance: a conceptual framework and survey. J Econ Lit 48(1) 58-107.

Adams R, Ferreira D (2007) A theory of friendly boards, J Financ 62(1) 217-250.

Adams R, Ferreira D (2009) Women in the boardroom and their impact on governance and performance, J Financ Econ 94(2) 291-309.

Aivazian V, Lai, T, Rahaman M. (2010). How do CEOs create value for their firms. working paper, University of Toronto.

Anderson R, Reeb D, Upadhya, A, Zhao W (2011) The economics of director heterogeneity, Financ Manag 40(1) 5-38.

Agrawal A, Knoeber C (1996) Firm performance and mechanisms to control agency problems between managers and shareholders, J Financ Quant Analysis,31(3) 377-397.

Bertrand M, Schoar A (2003) Managing with style: The effect of managers on firm policies. Q J Econ 118(4)1169-1208.

Bhagat S Black B (2002) The non-correlation between board independence and long-term firm performance, J Corp Law 27 231-273.

Black B, de Carvalh, A, Gorga E (2012) What matters and for which firms for corporate governance in emerging markets? Evidence from Brazil (and other BRIC countries). $J$ Corp Financ 18(4) 934-952.

Cadbury A (1992) Report of the Committee on the Financial Aspects of Corporate Governance, Gee Publishing, London.

Carter D, D'Souza F, Simkins B, Simpson W (2010) The gender and ethnic diversity of us boards and board committees and firm financial performance. Corp Gov: An Intl Rev 18(5) 396-414.

Cashman, Gillan S, Jun C (2012) Going overboard? On busy directors and firm value. J Bank Financ 36(12) 3248-3259.

Chen D (2008) The monitoring and advisory functions of corporate boards: theory and evidence, Working paper, SSRN.

Coles J, Daniel N, Naveen L (2008) Boards: does one size fit all? J Financ Econ,87(2) 329356.

Core J, Holthausen R, Larcker D (1999) corporate governance, CEO compensation, and firm performance. J Financ Econ 51(2) 371-406. 
Crespo-Cuaresma J, Gschwandtner A (2008). Tracing the dynamics of competition: evidence from company profits, Econ Inquiry 46(2) 208-213.

Custodio C, Metzger D (2013) How do CEOs matter? The effect of industry expertise on acquisition returns, Rev Financ Stud 26(8) 2008-2047.

Dahya J, Dimitrov O, McConnell J (2008) Dominant shareholders, corporate boards, and corporate value: a cross-country analysis. J Financ Econ 87(1), 73-100

DeFond M, Park C (1999) The effect of competition on CEO turnover. J Acc Econ 27(1) 3556.

Drakos A, Bekiris F (2010) Endogeneity and the relationship between board structure and firm performance: a simultaneous equation analysis for the Athens Stock Exchange, Manag Decis Econ 31(6) 387-401.

Faccio M, Lasfer A (2000) Do occupational pension funds monitor companies in which they hold large stakes? J Corp Financ 6(1) 71-110.

Fahlenbrach R, Low A, Stulz R M. (2010) Why do firms appoint CEOs as outside directors? J Financ Econ 97(1) 12-32.

Faleye O (2011) CEO directors, executive incentives, and corporate strategic initiatives. $J$ Financ Res 34(2) 241-277.

Ferris S. P, Jagannathan M, Pritchard A (2003) Too busy to mind the Bus? Monitoring by directors with multiple board appointments. J Financ 58 1087-1111.

Fich E (2005) Are some outside directors better than others? Evidence form director appointments by Fortune 1000 firms, J Bus 78(5) 1943-1971.

Fich E, Shivdasani A (2006) Are busy boards effective monitors? J Financ 61(2) 689-724.

Field, L, Lowry M, Mkrtchyan A (2013) Are busy boards detrimental? J Financ Econ, 109 (1) 63-82.

Goddard J, Wilson, JOS (1999) The persistence of profit: a new empirical interpretation. Int J Ind Organ, 17 663-687.

Goergen M (2012) International Corporate Governance. Pearson, London.

Gregory-Smith I (2012) Chief executive pay and remuneration committee independence. Oxf Bull Econ Stat 74(4) 510-531.

Guest P (2008) The determinants of board size and composition: evidence from the UK, $J$ Corp Financ 14(1) 51-72.

Hermalin B, Weisbach M (2003) Boards of directors as an endogenously determined institution, FRBNY Econ Pol Rev 9 7-26.

Higgs Report (2003) Review of the Role and Effectiveness of Non-Executive Directors, Department of Trade and Industry, London. 
Johnson S, Schnatterly K, Hill A D (2013) Board composition beyond independence: social capital, human capital, and demographics. J Manag 39(1) 232-262.

Kang S (2012) Experienced Independent Directors. University of Michigan - Stephen M. Ross School of Bus, mimeo.

Kaplan S, Reishus D (1990) Outside directorships and corporate performance, J Financ Econ 27(2) 389-410.

Knyazeva A, Knyazeva D, Masulis R (2012) The supply of corporate directors and board independence. Rev Financ Stud 26(6): 1561-1605.

Li H, Qian, Y (2011) Outside CEO directors on compensation committees: whose side are they on? Rev Acc Financ 10(2) 110-133.

Lublin JS (2012) Are executives overboarded? Wall Street J. February 29, 2012.

McKnight PJ, Weir C (2009) Agency costs, corporate governance mechanisms and ownership structure in large UK publicly quoted companies: a panel data analysis, $Q$ Rev Econ Financ 49 139-158.

Mehran H, (1995) Executive Compensation Structure, Ownership, and Firm Performance, $J$ Financ Econ 38(2) 163-84.

Mura R. (2007) Firm performance: do non-executive directors have minds of their own? Evidence from UK panel data, Financ Manag 36(3), 81-112.

Muravyev A (2003) Turnover of senior managers in Russian privatized firms, Comp Econ Stud, 52(2) 148-72.

Nordberg D (2011) Corporate Governance: Principles and Issues. Sage Puublications, London.

Parrino R (1997) CEO turnover and outside succession a cross-sectional analysis. J Financ Econ 46(2) 165-197.

Richardson S, Tuna A, Wysocki P (2003) Account for taste: board member preferences and Corp policy choices. Working paper Sloane School of Management, Massachssetts Institute of Technology

Shleifer A, Vishny R (1997) A survey of corporate governance. J Financ 52(2) 737-783.

Stiles P, (2013) Board Committees. In Wright M, Siegel D, Keasey K, Filatotchev I Oxford Handbook of Corporate Governance. Oxford University Press.

Spencer Stuart (2012 a) Board Index. Spencer Stuart, New York.

Spencer Stuart (2012 b) UK Board Index. Spencer Stuart, New York.

UK Corporate Governance Code (2010) Financial Reporting Council, London.

Vafeas N. (2003) Length of board tenure and outside director independence. $J$ Bus Financ Acc 30(7-8) 1043-1064. 
Weir C, Laing D, McKnight PJ (2002) Internal and external governance mechanisms: their impact on the performance of large UK public companies, J Bus Financ Acc 29(5-6) 579611.

Weir C, Laing D (2003) Ownership structure, board composition and the market for corporate control in the UK: an empirical analysis, App Econ 35(16) 1747-1759.

Wintoki M, Linck J, Netter J (2012) Endogeneity and the dynamics of internal corporate governance. J Financ Econ 105(3) 581-606.

Yermack D (1996) Higher market valuation of companies with small board of directors, $J$ Financ Econ 40 (2) 185-211. 
Table 1: Sample descriptive statistics.

\begin{tabular}{lcccc}
\hline Variable & Mean & Sd & Median & $\mathrm{N}$ \\
\hline NXXD & 0.20 & 0.40 & 0.00 & 3,997 \\
Share of NXXD directors & 0.06 & 0.13 & 0.00 & 3,997 \\
Number of NXXD directors & 0.24 & 0.51 & 0.00 & 3,997 \\
Leverage & 0.21 & 0.16 & 0.19 & 3,807 \\
Size & 6.51 & 2.05 & 6.42 & 3,985 \\
Board Size & 7.23 & 2.66 & 7.00 & 3,997 \\
Share NE & 0.52 & 0.14 & 0.50 & 3,997 \\
New NX & 0.50 & 0.50 & 0.00 & 3,997 \\
NX3 & 0.05 & 0.09 & 0.00 & 3,997 \\
ROE & 0.06 & 0.23 & 0.09 & 3,997 \\
ROS & 0.04 & 0.15 & 0.05 & 3,539 \\
Tobin's Q & 1.07 & 0.71 & 0.88 & 3,959 \\
Relative ROE of Exec Companies & 0.02 & 0.13 & 0.00 & 3,977 \\
Relative ROS of Exec Companies & 0.01 & 0.06 & 0.00 & 3,889 \\
Relative Tobin's Q of Exec Companies & 0.22 & 0.56 & 0.00 & 3,977 \\
Audit & 0.10 & 0.30 & 0.00 & 3,997 \\
\hline
\end{tabular}

Notes: NXXD is a dummy variable which has the value of 1 if a non-executive director is also an executive director in another company and 0 otherwise. Share of NXXD directors is the ratio of the number of nonexecutive directors on the board that are also executive directors in other firms to the total number of nonexecutive directors. Number of NXXD directors is the number of non-executive directors on the board who are executive directors in other companies. Leverage is the ratio of long term debt to total assets. Size is the natural $\log$ of the number of employees. Board size is the total number of directors on the board. Share NE is the percentage of non-executive directors on the board. New $N X$ is a dummy variable which has the value 1 if there is a new non-executive director and 0 if not. $N X 3$ is a dummy variable which has the value 1 if at least one nonexecutive director serves on three boards and 0 otherwise. $R O E$ is defined as profit before tax divided by book value of shareholders' equity. ROS, is defined as profit before tax divided by total turnover. Tobin's $Q$ is the market value of the firm divided by the book value of its assets. Relative ROE of Exec Companies is the average profitability of the firms where non-executive directors are employed as executive directors. Relative ROS of Exec Companies is the average profitability of the firms where the non-executive directors are employed as executive directors. Relative Tobin's $Q$ of Exec Companies is the average $\mathrm{Q}$ ratio of the firms where the nonexecutive directors are employed as executive directors. Audit is a dummy variable which takes the value of 1 if an NXXD sits in the audit committee and 0 otherwise. 
Table 2: Univariate analysis of key characteristics of companies with and without NXXDs.

\begin{tabular}{lcccccccc}
\hline & \multicolumn{3}{c}{ No NXXDs } & \multicolumn{3}{c}{ Yes NXXDs } & Mean & Median \\
\hline Variable & Mean & Sd & $\mathrm{N}$ & Mean & Sd & $\mathrm{N}$ & Diff & Diff \\
\hline Leverage & 0.20 & 0.16 & 3,028 & 0.24 & 0.16 & 779 & $-0.04^{* * *}$ & $-0.05^{* * *}$ \\
Size & 6.29 & 1.99 & 3,181 & 7.38 & 2.05 & 804 & $-1.08^{* * *}$ & $-1.05^{* * *}$ \\
Board Size & 6.94 & 2.57 & 3,189 & 8.37 & 2.72 & 808 & $-1.42^{* * *}$ & $-1.00^{* * *}$ \\
Share NE & 0.51 & 0.14 & 3,189 & 0.57 & 0.12 & 808 & $-0.06^{* * *}$ & $-0.07^{* * *}$ \\
New NX & 0.48 & 0.50 & 3,189 & 0.58 & 0.49 & 808 & $-0.11^{* * *}$ & $0.00^{\text {a }}$ \\
NX3 & 0.05 & 0.09 & 3,189 & 0.06 & 0.08 & 808 & -0.00 & $0.00^{\text {a }}$ \\
ROE & 0.05 & 0.24 & 3,189 & 0.11 & 0.22 & 808 & $-0.06^{* * *}$ & $-0.03^{* * *}$ \\
ROS & 0.03 & 0.16 & 2,818 & 0.06 & 0.13 & 721 & $-0.03^{* * *}$ & $-0.01^{* * *}$ \\
Tobin’s Q & 1.06 & 0.71 & 3,157 & 1.12 & 0.70 & 802 & $-0.06^{* * *}$ & $-0.06^{* * *}$ \\
\hline
\end{tabular}

Notes: Asterisks $* * *$ and $* *$ denote statistical significance at the $1 \%$ and 5\% levels, respectively. Mean Diff is a t-test for the difference between the means. Median Diff is the difference between the medians with significance levels based on the K-sample test. Leverage is the ratio of long term debt to total assets. Size is the natural log of the number of employees. Board size is the total number of directors on the board. New $N X$ is a dummy variable which takes the value 1 if there is a new non-executive director in a given year and 0 otherwise. $N X 3$ is a dummy variable which has the value 1 if at least one non-executive director serves on three boards and 0 if not. Share $N E$ is the percentage of non-executive directors on the board. $R O E$ is defined as profit before tax divided by book value of shareholders' equity. ROS is defined as profit before tax divided by total turnover. Tobin's $Q$ is the market value of the firm divided by the book value of its assets.

${ }^{\mathrm{a}}$ The K-sample test is not performed for binary variables. 
Table 3: Fixed effects regression results for the basic specification testing the overall effect of NXXDs on company performance.

Dependent Variables:

\begin{tabular}{lcccccc}
\hline & ROE & ROS & Tobin's Q & ROE & ROS & Tobin's Q \\
\hline NXXD & $(1)$ & $(2)$ & $(3)$ & $(4)$ & $(5)$ & $(6)$ \\
Number of NXXDs & $0.027 * *$ & $0.012^{*}$ & -0.002 & & & \\
& $(0.012)$ & $(0.006)$ & $(0.029)$ & & & \\
Board Size & & & & $0.016^{*}$ & $0.010^{* *}$ & -0.004 \\
& & & & $(0.009)$ & $(0.005)$ & $(0.022)$ \\
Share NE & 0.004 & 0.002 & 0.006 & 0.004 & 0.002 & 0.006 \\
& $(0.003)$ & $(0.002)$ & $(0.005)$ & $(0.003)$ & $(0.002)$ & $(0.005)$ \\
New NX & -0.058 & -0.009 & -0.062 & -0.057 & -0.009 & -0.061 \\
& $(0.059)$ & $(0.039)$ & $(0.105)$ & $(0.059)$ & $(0.039)$ & $(0.105)$ \\
NX3 & 0.005 & 0.001 & 0.005 & 0.005 & 0.001 & 0.005 \\
& $(0.008)$ & $(0.005)$ & $(0.016)$ & $(0.008)$ & $(0.005)$ & $(0.016)$ \\
Leverage & 0.073 & 0.032 & 0.120 & 0.071 & 0.032 & 0.120 \\
& $(0.059)$ & $(0.030)$ & $(0.142)$ & $(0.059)$ & $(0.030)$ & $(0.142)$ \\
Size & -0.017 & $-0.070^{* *}$ & $-0.235^{*}$ & -0.016 & $-0.069 * *$ & $-0.234^{*}$ \\
& $(0.061)$ & $(0.035)$ & $(0.127)$ & $(0.061)$ & $(0.035)$ & $(0.127)$ \\
Lagged ROE & $-0.032^{* * *}$ & -0.012 & $-0.115^{* * *}$ & $-0.032 * * *$ & -0.012 & $-0.115^{* * *}$ \\
& $(0.012)$ & $(0.010)$ & $(0.025)$ & $(0.012)$ & $(0.010)$ & $(0.025)$ \\
Firm-years & & & -0.040 & & & -0.040 \\
Firms & & & $(0.054)$ & & & $(0.054)$ \\
R2 & 3,997 & 3,580 & 3,951 & 3,997 & 3,580 & 3,951 \\
& 1,224 & 1,092 & 1,220 & 1,224 & 1,092 & 1,220 \\
& 0.06 & 0.02 & 0.21 & 0.06 & 0.02 & 0.21 \\
\hline
\end{tabular}

Notes: Robust standard errors are in parentheses. A constant and time dummy variables are included in the regressions but not reported. Asterisks denote significance levels: * significant at 10\%, ** significant at 5\%, *** significant at $1 \%$. ROE is defined as profit before tax divided by book value of shareholders' equity. ROS is defined as profit before tax divided by total turnover. Tobin's $Q$ is the market value of the firm divided by book value of its assets. NXXD is a dummy variable which has the value of 1 if a non-executive director is also an executive director in another company and 0 if not. Number of NXXDs is the number of non-executive directors on the board who are executive directors in other companies. Board size is the total number of directors on the board. Share NE is the percentage of non-executive directors on the board. New NX is a dummy variable which takes the value 1 if there is a new non-executive director in a given year and 0 if not. NX3 is a dummy variable which has the value 1 if at least one non-executive director serves on three boards and 0 otherwise. Leverage is the ratio of long term debt to total assets. Size is the natural log of the number of employees. 
Table 4: Fixed effects regression results: Specifications with relative performance and industry similarity.

\begin{tabular}{|c|c|c|c|c|c|c|c|c|c|}
\hline \multicolumn{10}{|c|}{ Dependent Variable } \\
\hline & ROE & ROS & Tobins Q & ROE & ROS & Tobins Q & ROE & ROS & Tobins Q \\
\hline & (1) & $(2)$ & (3) & (4) & (5) & (6) & (7) & (8) & (9) \\
\hline \multirow[t]{2}{*}{ NXXD } & 0.020 & 0.004 & -0.035 & & & & & & \\
\hline & $(0.013)$ & $(0.008)$ & $(0.042)$ & & & & & & \\
\hline \multirow[t]{2}{*}{ NXXD X Diff } & & & & 0.022 & 0.000 & -0.047 & 0.022 & -0.002 & -0.028 \\
\hline & & & & $(0.015)$ & $(0.009)$ & $(0.043)$ & $(0.015)$ & $(0.009)$ & $(0.040)$ \\
\hline \multirow[t]{2}{*}{ NXXD X Same } & & & & 0.012 & 0.020 & 0.027 & 0.011 & 0.021 & -0.055 \\
\hline & & & & $(0.021)$ & $(0.017)$ & $(0.068)$ & $(0.021)$ & $(0.016)$ & $(0.115)$ \\
\hline \multirow[t]{2}{*}{ Rel Perf } & $0.050 *$ & $0.107 * *$ & 0.023 & $0.050 *$ & $0.112 * *$ & 0.022 & & & \\
\hline & $(0.027)$ & $(0.047)$ & $(0.030)$ & $(0.027)$ & $(0.048)$ & $(0.030)$ & & & \\
\hline \multirow[t]{2}{*}{ Rel Perf X Diff } & & & & & & & 0.064 & -0.038 & 0.092 \\
\hline & & & & & & & $(0.080)$ & $(0.087)$ & $(0.099)$ \\
\hline \multirow[t]{2}{*}{ Rel Perf X Same } & & & & & & & 0.048 & $0.149 * *$ & 0.005 \\
\hline & & & & & & & $(0.030)$ & $(0.062)$ & $(0.028)$ \\
\hline Firm-years & 3,977 & 3,501 & 3,931 & 3,977 & 3,501 & 3,931 & 3,977 & 3,501 & 3,931 \\
\hline Firms & 1,224 & 1,075 & 1,220 & 1,224 & 1,075 & 1,220 & 1,224 & 1,075 & 1,220 \\
\hline R2 & 0.06 & 0.03 & 0.21 & 0.06 & 0.03 & 0.21 & 0.06 & 0.03 & 0.21 \\
\hline
\end{tabular}

Notes: Robust standard errors are in parentheses. A constant, time dummies, variables Board size, Share NE, New NX, NX3, Leverage and Size are included in all regressions but not reported. ROE is included in Tobin’s Q regressions but not reported. Asterisks denote significance levels: * significant at $10 \%$, ** significant at $5 \%$, *** significant at $1 \%$. ROE is defined as profit before tax divided by book value of shareholders' equity. ROS is defined as profit before tax divided by total turnover. Tobin's $Q$ is the market value of the firm divided by the book value of its assets. NXXD X Diff is a dummy variable that equals 1 if a firm has at least one NXXD who works in a different industry and 0 otherwise. NXXD X Same is a dummy variable which takes the value of 1 if at least one of the firm's non-executive directors has an executive position in the same industry and 0 otherwise. Rel Perf is the average relative performance of the companies in which the non-executive directors act as executive directors. 
Table 5: Fixed effects regression results: Specifications with relative performance, industry similarity and audit committee membership.

\begin{tabular}{|c|c|c|c|c|c|c|}
\hline & \multicolumn{6}{|c|}{ Dependent Variable } \\
\hline & ROE & ROS & Tobins Q & ROE & ROS & Tobins Q \\
\hline & (1) & (2) & (3) & (4) & (5) & (6) \\
\hline \multirow[t]{2}{*}{$\overline{N X X D}$} & 0.022 & 0.004 & -0.070 & & & \\
\hline & $(0.014)$ & $(0.009)$ & $(0.043)$ & & & \\
\hline \multirow[t]{2}{*}{ NXXD Diff } & & & & $0.027 *$ & 0.003 & $-0.073 *$ \\
\hline & & & & $(0.016)$ & $(0.009)$ & $(0.044)$ \\
\hline \multirow[t]{2}{*}{ NXXD Same } & & & & 0.002 & 0.007 & -0.041 \\
\hline & & & & $(0.022)$ & $(0.016)$ & $(0.070)$ \\
\hline \multirow[t]{2}{*}{ Rel Perf } & $0.051 *$ & $0.107 * *$ & 0.022 & $0.050^{*}$ & $0.114 * *$ & 0.022 \\
\hline & $(0.027)$ & $(0.047)$ & $(0.029)$ & $(0.028)$ & $(0.048)$ & $(0.029)$ \\
\hline \multirow[t]{2}{*}{ Audit } & -0.005 & 0.001 & $0.081 * *$ & & & \\
\hline & $(0.017)$ & $(0.009)$ & $(0.037)$ & & & \\
\hline \multirow{2}{*}{ Audit X Diff } & & & & -0.011 & -0.006 & 0.065 \\
\hline & & & & $(0.019)$ & $(0.010)$ & $(0.041)$ \\
\hline \multirow[t]{2}{*}{ Audit X Same } & & & & 0.025 & 0.032 & $0.144^{* *}$ \\
\hline & & & & $(0.031)$ & $(0.023)$ & $(0.057)$ \\
\hline Firm-years & 3,977 & 3,501 & 3,931 & 3,977 & 3,501 & 3,931 \\
\hline Firms & 1,224 & 1,075 & 1,220 & 1,224 & 1,075 & 1,220 \\
\hline $\mathrm{R} 2$ & 0.06 & 0.03 & 0.21 & 0.06 & 0.03 & 0.21 \\
\hline
\end{tabular}

Notes: Robust standard errors are in parentheses. A constant, time dummies, variables Board size, Share NE, New NX, NX3, Leverage and Size are included in all regressions but not reported. ROE is included in Tobin's Q regressions but not reported. Asterisks denote significance levels: * significant at $10 \%, * *$ significant at $5 \%$, *** significant at $1 \%$. ROE is defined as profit before tax divided by book value of shareholders' equity. ROS is defined as profit before tax divided by total turnover. Tobin's $Q$ is the market value of the firm divided by the book value of its assets. NXXD X Diff is a dummy variable that equals 1 if a firm has at least one NXXD who works in a different industry and 0 otherwise. NXXD Same is 1 if the NXXD director is also an executive director in a company in the same industry and 0 otherwise. Rel Perf is the average relative performance of the companies in which the non-executive directors act as executive directors. Audit is a dummy variable which takes the value of 1 if there is an NXXD in the audit committee and 0 if not. 
Table 6: GMM-SYS dynamic panel data regressions results.

\begin{tabular}{|c|c|c|c|c|c|c|}
\hline & \multicolumn{6}{|c|}{ Dependent Variable } \\
\hline & ROE & ROS & Tobin’s Q & $\mathrm{ROE}$ & ROS & Tobin’s Q \\
\hline & (1) & $(2)$ & (3) & (4) & (5) & (6) \\
\hline NXXD & $\begin{array}{l}0.074 * * \\
(0.033)\end{array}$ & $\begin{array}{l}0.050^{* * *} \\
(0.018)\end{array}$ & $\begin{array}{l}0.108 \\
(0.081)\end{array}$ & & & \\
\hline Number of NXXDs & & & & $\begin{array}{l}0.056^{* *} \\
(0.026)\end{array}$ & $\begin{array}{l}0.047 * * * \\
(0.015)\end{array}$ & $\begin{array}{l}0.061 \\
(0.067)\end{array}$ \\
\hline Board Size & $\begin{array}{l}0.001 \\
(0.005)\end{array}$ & $\begin{array}{l}0.001 \\
(0.004)\end{array}$ & $\begin{array}{l}0.001 \\
(0.010)\end{array}$ & $\begin{array}{l}-0.000 \\
(0.005)\end{array}$ & $\begin{array}{l}0.001 \\
(0.004)\end{array}$ & $\begin{array}{l}-0.003 \\
(0.010)\end{array}$ \\
\hline Share NE & $\begin{array}{l}0.109 \\
(0.150)\end{array}$ & $\begin{array}{l}0.029 \\
(0.090)\end{array}$ & $\begin{array}{l}0.135 \\
(0.352)\end{array}$ & $\begin{array}{l}0.128 \\
(0.151)\end{array}$ & $\begin{array}{l}0.038 \\
(0.089)\end{array}$ & $\begin{array}{l}0.167 \\
(0.354)\end{array}$ \\
\hline New NX & $\begin{array}{l}0.025 \\
(0.042)\end{array}$ & $\begin{array}{l}0.006 \\
(0.028)\end{array}$ & $\begin{array}{l}-0.130 \\
(0.099)\end{array}$ & $\begin{array}{l}0.035 \\
(0.043)\end{array}$ & $\begin{array}{l}0.010 \\
(0.029)\end{array}$ & $\begin{array}{l}-0.116 \\
(0.096)\end{array}$ \\
\hline NX3 & $\begin{array}{l}-0.034 \\
(0.142)\end{array}$ & $\begin{array}{l}-0.034 \\
(0.080)\end{array}$ & $\begin{array}{l}0.218 \\
(0.331)\end{array}$ & $\begin{array}{l}-0.032 \\
(0.143)\end{array}$ & $\begin{array}{l}-0.026 \\
(0.080)\end{array}$ & $\begin{array}{l}0.219 \\
(0.329)\end{array}$ \\
\hline Leverage & $\begin{array}{l}-0.232 \\
(0.164)\end{array}$ & $\begin{array}{l}-0.168 * * \\
(0.079)\end{array}$ & $\begin{array}{l}0.168 \\
(0.367)\end{array}$ & $\begin{array}{l}-0.220 \\
(0.163)\end{array}$ & $\begin{array}{l}-0.162 * * \\
(0.081)\end{array}$ & $\begin{array}{l}0.210 \\
(0.371)\end{array}$ \\
\hline Size & $\begin{array}{l}0.012 \\
(0.021)\end{array}$ & $\begin{array}{l}-0.002 \\
(0.013)\end{array}$ & $\begin{array}{l}-0.112 * * \\
(0.054)\end{array}$ & $\begin{array}{l}0.010 \\
(0.021)\end{array}$ & $\begin{array}{l}-0.001 \\
(0.013)\end{array}$ & $\begin{array}{l}-0.110^{* *} \\
(0.054)\end{array}$ \\
\hline Lagged Performance & $\begin{array}{l}0.349 * * * \\
(0.112)\end{array}$ & $\begin{array}{l}0.260^{*} \\
(0.142)\end{array}$ & $\begin{array}{l}0.424 * * * \\
(0.080)\end{array}$ & $\begin{array}{l}0.358 * * * \\
(0.112)\end{array}$ & $\begin{array}{l}0.267 * \\
(0.145)\end{array}$ & $\begin{array}{l}0.425 * * * \\
(0.081)\end{array}$ \\
\hline ROE & & & $\begin{array}{l}0.051 \\
(0.221)\end{array}$ & & & $\begin{array}{l}0.096 \\
(0.226)\end{array}$ \\
\hline Firm-years & 3,961 & 3,544 & 3,933 & 3,961 & 3,544 & 3,933 \\
\hline Firms & 1,213 & 1,080 & 1,213 & 1,213 & 1,080 & 1,213 \\
\hline Hansen(p-val) & 0.08 & 0.75 & 0.11 & 0.10 & 0.81 & 0.09 \\
\hline AR2 (p-val) & 0.20 & 0.46 & 0.75 & 0.22 & 0.50 & 0.79 \\
\hline
\end{tabular}

Note: Robust standard errors are in parentheses. A constant and time dummy variables are included in the regressions but not reported. Asterisks denote significance levels: * significant at $10 \%$, ** significant at 5\%, *** significant at 1\%. ROE is defined as profit before tax divided by book value of shareholders' equity. ROS is defined as profit before tax divided by total turnover. Tobin's $Q$ is the market value of the firm divided by the book value of its assets. $N X X D$ is a dummy variable which has the value of 1 if a non-executive director is also an executive director in another company and 0 otherwise. Number of NXXD directors is the number of nonexecutive directors on the board who are executive directors in other companies. Board size is the total number of directors on the board. Share $N E$ is the percentage of non-executive directors on the board. New NX is a dummy variable which has the value 1 if there is a new non-executive director in a given year and 0 otherwise. $N X 3$ is a dummy variable which has the value 1 if at least one non-executive director serves on three boards and 0 if not. Leverage is the ratio of long term debt to total assets. Size is the natural log of the number of employees. 